\title{
'Dot in circle sign' in thigh: an unusual site of mycetoma
}

\author{
Gurpreet Sandhu, ${ }^{\oplus 1}$ Mahesh Prakash, ${ }^{1}$ Tarun Narang ${ }^{2}$
}

${ }^{1}$ Department of Radiodiagnosis and Imaging, Post Graduate Institute of Medical Education and Research, Chandigarh, India ${ }^{2}$ Department of Dermatology, Venereology and Leprology, Post Graduate Institute of Medical Education and Research, Chandigarh, India

\section{Correspondence to} Dr Gurpreet Sandhu, gurpreetsandhu1529@gmail. com

Accepted 28 April 2019
Check for updates

(C) BMJ Publishing Group Limited 2019. No commercial re-use. See rights and permissions. Published by BMJ.

To cite: Sandhu G,
Prakash M, Narang T. BMJ
Case Rep 2019;12:e229499.
doi:10.1136/bcr-2019-
229499

\section{DESCRIPTION}

A 39-year-old man presented with nodular swelling and multiple sinuses discharging black grains on the medial aspect of right thigh for last two and a half years. The patient initially developed a small nodule in the thigh for which he underwent incision and drainage outside. The patient had partial symptomatic improvement and over the course of time developed multiple similar nodules and sinuses draining serosanguineous fluid at the same site. The patient had a history of trauma to right thigh by bull horn injury 8 years back following which he developed a wound on thigh for which daily dressing was done. There was no history of fever, weight loss or loss of appetite, diabetes mellitus or tuberculosis. The patient had no history of drug abuse.

Patient was investigated further in our hospital and haematological and biochemical panels were within normal limits. Smears were made from the local site which was negative for bacteria, pus cells, yeast cells and cryptococcus. Acid fast bacilli and Gram stain failed to highlight any organism.

Contrast enhanced MRI thigh was done which revealed a large ill-defined soft tissue lesion measuring $\sim 11.5 \times 5.2 \mathrm{~cm}$ in the intramuscular plane (involving vastus medialis, intermedius, sartorius and adductor group of muscles) on the medial aspect of mid and distal right thigh with nodules and sinus tracts reaching up until skin surface with multiple tiny T2 hypointense foci within giving 'dot in circle sign'(figure 1A, B). No obvious areas of necrosis were seen. The lesion was partially encasing the distal superficial femoral artery and vein. A likely possibility of atypical fungal/bacterial infection likely mycetoma was kept. Patient underwent fine needle aspiration cytology from the

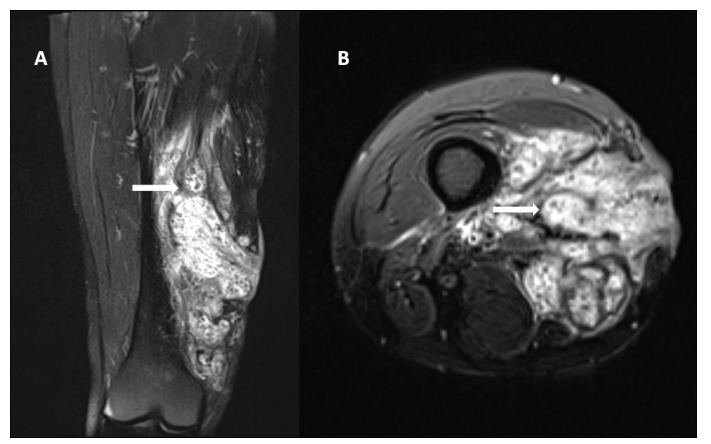

Figure 1 ( $A, B)$ MRI coronal and axial T2 weighted images showing large ill-defined soft tissue lesion on medial aspect of thigh with nodules and sinus tract reaching up until skin surface with multiple tiny $\mathrm{T} 2$ hypointense foci within giving 'dot in circle sign' (arrow).

\section{Patient's perspective}

Early diagnosis and treatment is required for management of any disease with all relevant investigations should be done timely to avoid complication as in my case.

\section{Learning points}

- 'Dot in circle sign' on MRI-important indicator of mycetoma infection.

- Foot is the most common location for mycetoma, however thigh is a rare site for its occurrence.

lesion which revealed foamy macrophages, neutrophils and capillary fragments with eosinophils in a necrotic background. Periodic acid-Schiff stain highlighted fragmented pigmented fungal hyphae suggestive of fungal infection. Culture confirmed the diagnosis. Patient was started on antifungals (itraconazole $200 \mathrm{mg}$ two times per day) resulting in decreased discharge and swelling from the infected site over few days. Patient has been kept on follow-up with advice for debulking surgery.

Mycetoma is a chronic granulomatous disease seen in tropical countries with clinical and histopathological diagnosis being required for confirmation. On MRI the mycetoma shows tiny hypointense foci within the hyperintense spherical lesions, giving the classical 'dot in circle sign'. This sign has high sensitivity and is useful for making early diagnosis non-invasively. The central hypointense dot represents fungal ball or grains, the surrounding hyperintense area is the inflammatory granuloma and the peripheral hypointense rim being the fibrous matrix. On ultrasounda similar sign has been described with multiple hypoechoic lesions showing a sharp central hyperechoic foci representing the eumycetoma grain. The the most common location for mycetoma is foot however in our index case there was an unusual presentation in thigh. ${ }^{12}$

Funding The authors have not declared a specific grant for this research from any funding agency in the public, commercial or not-for-profit sectors.

Competing interests None declared.

Patient consent for publication Obtained.

Provenance and peer review Not commissioned; externally peer reviewed.

\section{REFERENCES}

1 Sen A, Pillay RS. Case report: Dot-in-circle sign - An MRI and USG sign for "Madura foot". Indian J Radiol Imaging 2011;21:264-6.

2 Roberts IF, Karim QN, Rosin RD. Actinomycotic mycetoma of the thigh. J R Soc Med 1989;82:552-3. 
Images in...

Copyright 2019 BMJ Publishing Group. All rights reserved. For permission to reuse any of this content visit https://www.bmj.com/company/products-services/rights-and-licensing/permissions/

BMJ Case Report Fellows may re-use this article for personal use and teaching without any further permission.

Become a Fellow of BMJ Case Reports today and you can:

- Submit as many cases as you like

- Enjoy fast sympathetic peer review and rapid publication of accepted articles

Access all the published articles

- Re-use any of the published material for personal use and teaching without further permission

For information on Institutional Fellowships contact consortiasales@bmjgroup.com

Visit casereports.bmj.com for more articles like this and to become a Fellow 